\title{
ANALISIS INCOME SMOOTHING DAN EARNING RESPONSE (STUDI PADA PERUSAHAAN SEKTOR INDUSTRI BARANG KONSUMSI YANG TERDAFTAR DI BURSA EFEK INDONESIA)
}

\author{
Oleh: \\ Stevan Theodore \\ S1 Akuntansi \\ Yansen Siahaan, Jubi, Ady Inrawan
}

Abstraksi

Tujuan Penelitian ini adalah menganalisis dan mengetahui perkembangan income smoothing dan earning response pada Perusahaan Sektor Industri Barang Konsumsi yang terdaftar di Bursa Efek Indonesia. Penelitian ini dilakukan dengan menggunakan metode analisis deskriptif dan komparatif. Penelititan ini dilakukan berdasarkan data sekunder dari laporan keuangan perusahaan yang diperoleh dari Indonesia Exchange Statistik.

Hasil penelitian dapat disimpulkan sebagai berikut: 1) Jumlah perusahaan yang melakukan praktik Income Smoothing sebanding dengan perusahaan yang tidak melakukan praktik Income Smoothing. 2) Terdapat perusahaan yang tidak melakukan tindakan Income Smoothing walaupun perusahaan tersebut mengalami penurunan laba. 3) Perusahaan dapat melakukan tindakan Income Smoothing dalam jumlah yang signifikan selama masih sesuai dengan Standar Akuntansi Keuangan Indonesia. 4) Besarnya Cummulative Abnormal Return menunjukkan besarnya Earning Response terhadap harga saham pada perusahaan tersebut. 5) Earning Response yang berkurang disebabkan karena harga saham perusahaan yang menurun dalam jumlah yang cukup besar. Hasil penelitian menyarankan agar perusahaan melaporkan laba yang sebenarnya tanpa melakukan Income Smoothing dan juga diharapkan dapat menjaga harga saham untuk mendapatkan Earning Response yang bagus.

Kata kunci: Income Smoothing dan Earning Response

\section{Abstraction}

The purpose of this study to analyze and determine the development of income smoothing and earnings response on Consumer Goods of Industrial Sector Companies listed on the Indonesia Stock Exchange. This research was conducted by using descriptive and comparative analysis. This research is done based on secondary data from company financial reports obtained from the Indonesian Exchange Statistics.

The results of the research can be summarized as follows: 1) The number of companies that engage in the practice of Income Smoothing comparable to companies that do not engage in the practice of Income Smoothing. 2) There is company that do not take action of Income Smoothing though the company experienced a decline in profits. 3) The company can take action of Income Smoothing in significant numbers as long as it is still in accordance with Indonesian Accounting Standard. 4) Size of cummulative Abnormal Return shows the size of the Earning Response to the stock price of the company. 5) Earning Response reduced due to the decreases of company's stock price in large amount of quantities. The results of the research suggest that companies report actual profits without doing Income Smoothing and is also expected to maintain the stock price to get a good Earning Response.

Keywords: Income Smoothing and Earnings Response 


\section{A. PENDAhUluAN}

\section{Latar Belakang Masalah}

Laba sebagai salah satu informasi penting bagi pihak internal maupun pihak eksternal merupakan besarnya pendapatan dari kegiatan penjualan sebagai selisih dari keseluruhan usaha yang terdapat biaya yang dikeluarkan untuk proses penjualan selama periode tertentu. Harga saham perusahaan sendiri sering mengalami perubahan yang cukup dinamis dan menyebabkan banyak diperjual-belikan di pasar sekunder.

Pengumuman laba perusahaan juga merupakan informasi penting yang mencerminkan nilai perusahaan bagi pelaku pasar. Deskriptif atas perusahaan inilah yang membuat penulis berasumsi bahwa tidak tertutup kemungkinan ada beberapa manajemen perusahaan tersebut untuk melakukan perataan laba. Hal tersebut dapat dilihat dari laporan laba-rugi beberapa perusahaan yang menunjukkan besarnya laba yang relatif stabil dari tahun ke tahun. Pihak manajemen juga membuka peluang untuk melakukan pengelolaan atas laba dengan melakukan income smoothing bila terjadi perubahan harga yang cukup dinamis.

Investor sering memusatkan perhatian pada informasi laba tanpa memperhatikan prosedur yang digunakan dalam menghasilkan informasi tersebut. Hal inilah yang mendorong manajer untuk melakukan manajemen untuk mengelola laba dalam usahanya sehingga tampak bagus secara finansial. Income smoothing menjadi salah satu alternatif manajemen perusahaan untuk mengurangi variasi abnormal laba yang tentunya masih dalam batas yang diijinkan dalam praktek akuntansi dan prinsip manajemen yang wajar.

Menurut Assih (2000:37), bila pengumuman laba tahunan mengandung informasi, maka variabilitas perubahan akan nampak lebih besar pada saat laba diumumkan daripada saat lain selama tahun bersangkutan karena terdapat perubahan dalam keseimbangan nilai harga saham selama periode pengumuman. Pengumuman laba sendiri mengandung informasi jika laba yang diumumkan berbeda dengan laba yang diprediksi oleh para investor. Pada kondisi inilah pasar akan bereaksi tercermin dalam pergerakan harga saham pada periode pengumuman tersebut.

\section{Rumusan Masalah}

"Bagaimana perkembangan Income Smoothing dan Earning Response pada Perusahaan Sektor Industri Barang Konsumsi yang terdaftar di Bursa Efek Indonesia?".

\section{Tujuan Penelitian}

Untuk menganalisis dan mengetahui perkembangan income smoothing dan earning response pada Perusahaan Sektor Industri Barang Konsumsi yang terdaftar di Bursa Efek Indonesia.

\section{Metode Penelitian}

Untuk memperoleh data dan informasi yang diperlukan peneliti, maka penulis mengakses situs dari Bursa Efek Indonesia yaitu http://www.idx.co.id. Objek penelitian yang digunakan adalah Perusahaan Sektor Industri Barang Konsumsi yang Terdaftar di Bursa Efek Indonesia yang memenuhi kriteria yaitu sebanyak 6 perusahaan.

Adapun Desain penelitian yang digunakan dalam penulisan skripsi ini adalah Penelitian Kepustakaan (Library Research). Teknik pengumpulan data yang dilakukan penulis dalam penelitian ini adalah metode dokumentasi. Adapun jenis data yang digunakan dalam penelitian ini adalah jenis data kualitatif dan data kuantitatif. Teknik analisa yang digunakan dalam penelitian adalah Metode Deskriptif dan Metode Komparatif.

\section{B. LANDASAN TEORI}

\section{Manajemen Laba}

Menurut Scott (2000:351), manajemen laba merupakan pemilihan kebijakan akuntansi untuk mencapai tujuan khusus yang meliputi pendapatan bonus dan kompensasi, mempengaruhi keputusan pelaku pasar modal, menghindari pelanggaran perjanjian hutang. Sementara itu, Belkaoui (2007:201), menyatakan bahwa pada dasarnya definisi operasional dari manajemen laba adalah potensi penggunaan manajemen akrual dengan tujuan memperoleh keuntungan pribadi. Jadi dapat disimpulkan bahwa manajemen laba adalah suatu tindakan yang dilakukan oleh manajemen perusahaan dalam pelaporan laba yang lebih merefleksikan kinerja manajemen perusahaan.

Manajemen laba berbeda dengan kecurangan. Perbedaan tersebut terletak pada tingkat kepatuhan terhadap standar akuntansi. Manajemen laba merupakan rekayasa pelaporan keuangan dalam batas-batas tertentu yang tidak melanggar standar pelaporan keuangan. Hal ini dilakukan oleh manajemen dengan memanfaatkan wewenangnya dalam memilih metode akuntansi yang diizinkan oleh standar. Manajer memiliki fleksibilitas dalam membuat pilihan metode maupun kebijakan akuntansi dari beberapa alternatif metode dan kebijakan akuntansi yang ada, yang menurut preferensi manajer paling menguntungkan pada periode pelaporan. Manajemen banyak memanfaatkan standar pelaporan keuangan dengan cara menerapkan standar yang dipercepat pengadobsiannya. Selain itu standar juga dijadikan sebagai alat untuk melaporkan kondisi perusahaan. Fleksibilitas yang terdapat dalam standar akuntansi pada akhirnya menyebabkan tindakan tersebut 
sah dengan sendirinya. Sedangkan kecurangan dalam pelaporan keuangan lebih merupakan upaya manajemen untuk menyembunyikan atau memanipulasi sebagian atau seluruh informasi keuangan dengan cara yang tidak sesuai dengan standar akuntansi yang berlaku.

Penjelasan konsep earning management dapat dimulai dari pendekatan agency dan signalling theory. Kedua teori ini membahas masalah perilaku manusia yang memiliki keterbatasan rasional (bounded rationality) dan menolak resiko (risk averse). Teori keagenan (agency theory) menyatakan bahwa praktik income smotthing dipengaruhi oleh adanya konflik kepentingan antara manajemen dengan pemilik yang timbul ketika setiap pihak berusaha untuk mencapai atau mempertahankan tingkat kemakmuran yang dikehendakinya. Dedhy (2011:142), menyatakan bahwa teori signal (signalling theory) sendiri membahas bagaimana seharusnya signal keberhasilan atau kegagalan manajemen disampaikan kepada pemilik. Penyampaian laporan keuangan dapat dianggap sebagai signal mengenai kinerja manajemen. Dalam hubungan keagenan, manajer mempunyai asimetri informasi terhadap pihak eksternal perusahaan seperti investor dan kreditor. Asimetri informasi terjadi ketika manajer mempunyai informasi tersebut relatif lebih cepat daripada pihak eksternal. Kondisi inilah yang memberikan kesempatan kepada manajer untuk menggunakan informasi yang diketahuinya untuk menata pelaporan keuangan sebagai usaha untuk memaksimalkan kemakmurannya.

\section{Income Smoothing}

Salah satu pola atau tindakan manajemen atas laba yang dapat dilakukan yaitu income smoothing (perataan laba). Menurut Belkaoui (2007:210), income smoothing adalah upaya yang sengaja dilakukan untuk menormalkan laba dalam rangka mencapai kecenderungan atau tingkat laba yang diinginkan. Sementara itu Husnan (2005:162), mengungkapkan tindakan perataan laba dapat didefenisikan sebagai suatu sara yang digunakan manajemen untuk mengurangi variabilitas urutan, dimana pelaporan laba relatif terhadap beberapa urutan target yang terlihat karena adanya manipulasi variabel akuntansi semu (artificial smoothing) atau transaksi riil (real smoothing). Jadi dapat disimpulkan bahwa perataan laba merupakan tindakan yang dilakukan dengan sengaja untuk mengurangi variabilitas laba yang dilaporkan agar dapat mengurangi risiko pasar atas saham perusahaan, yang pada akhirnya dapat meningkatkan harga saham perusahaan.

Alwi (2003:13), menyebutkan bahwa bentuk manipulasi laba adalah sebagai berikut:

a. Klasifikasi berita baik dan buruk dimana manajemen cenderung melaporkan berita baik sebagai bagian dari operasi dan melaporkan berita buruk sebagai pos luar biasa.

b. Perataan laba dimana manajemen dalam tahun yang baik mengurangi laba dan membesarkan laba pada tahun yang suram.

c. Big bath behavior yang merupakan kontras dari perataan laba dimana pada tahun yang suram, manajemen cenderung mengakui kerugian potensial sehingga pada tahun berikutnya tidak muncul.

d. Perubahan stabilitas yang dilakukan dengan meratakan laba, meratakan laba pesimis, melakukan standar deviasi dan mengindeks instabilitas laba.

Income smoothing (perataan laba) menggunakan skala pengukuran rasio. Untuk menentukan perusahaan sebagai perata laba dan bukan perata laba, diklasifikasikan menggunakan model Eckel (1981). Praktek perataan laba diuji dengan indeks Eckel yaitu menggunakan Coefficient Variation (CV) variabel penjualan bersih dan variabel penghasilan atau laba bersih. Dalam penelitian ini laba yang digunakan adalah laba setelah pajak sebagai tujuan perataăn lāba. Untuk menghitung income smoothing, dapat digunakan rumus sebagai berikut:

Indeks Eckel $=\frac{\mathrm{Cv}_{i}^{\text {earning }}}{\mathrm{Cv}_{\mathrm{i}}^{\text {sales }}} \ldots \ldots \ldots \ldots \ldots . . . .$. Eckel $(1981)$

Dimana:

$\mathrm{CV}_{i}^{\text {earning }} \quad$ : koefisien variasi untuk perubahan

$\mathrm{CV}_{i}^{\text {sales }} \quad:$ koefisien variasi untuk perubahan

penjualan (coefficients of variation of sales)

Indeks Eckel : indeks perataan laba (income

smoothing index)

Setelah diperoleh nilai Indeks Eckel, maka perusahaan dikelompokkan ke dalam perusahaan yang melakukan Income Smoothing jika Indeks Eckel > 1.

\section{Kandungan Informasi atas Laba dan Earning Response}

Menurut Baridwan (2004:29), laba berarti kenaikan modal atau aktiva bersih yang berasal dari transaksi sampingan atau transaksi yang jarang terjadi dari badan usaha dan dari semua transaksi atau kejadian lain yang mempengaruhi badan usaha selama satu periode kecuali yang termasuk dari pendapatan atau investasi oleh pemilik. Sementara itu menurut Simamora (2002:45), laba adalah perbandingan antara pendapatan dengan beban jikalau pendapatan melebihi beban maka hasilnya adalah laba bersih. Jadi menurut uraian diatas maka dapat disimpulkan bahwa laba berasal dari semua transaksi atau kegiatan yang terjadi pada badan usaha dan 
akan mempengaruhi kegiatan perusahaan pada periode tertentu dan laba didapat dari selisih antara pendapatan yang lebih besar daripada beban.

Menurut Jogiyanto (2000:212), Salah satu cara dalam mengukur variabel reaksi pasar adalah dengan menggunakan menggunakan Cummulative Abnormal Return (CAR) yang dihitung pada saat periode peristiwa (event period), yang disebut juga dengan periode pengamatan atau jendela peristiwa. Pada pengumuman laba, periode laba yang digunakan umumnya adalah 4 hari yaitu satu hari sebelum hari peristiwa dan tiga hari sesudahnya. Namun, untuk melihat ada tidaknya suatu reaksi atas pengumuman laba dapat menggunakan satu periode pengamatan (tiga hari setekah pengumuman laba). Cummulative Abnormal Return merupakan penjumlahan dari abnormal return pada periode pengamatan. Perhitungan abnormal return diperoleh dari selisih antara return untuk saham I pada hari t dengan return yang diharapkan dari saham tersebut. Secara sistematis, uraian tentang perhitungan cummulative abnormal return diatas dapat ditulis sebagai berikut:

$$
\begin{aligned}
& \mathrm{CAR}_{\text {it }}=\sum \mathrm{AR}_{i t} \quad \ldots \ldots \ldots \ldots . \text { Jogiyanto }(2000: 212) \\
& \text { Dimana : } \\
& \mathrm{CAR}_{\mathrm{it}} \text { : cummulative abnormal return saham I } \\
& \text { pada hari ke-t } \\
& \mathrm{AR}_{\text {it }} \quad \text { : abnormal return saham I pada hari ke-t }
\end{aligned}
$$

\section{Hubungan Income Smoothing terhadap Earning Response}

Beberapa penelitian yang dilakukan di pasar modal menunjukkan bahwa banyak perusahaan yang melakukan perataan laba untuk tujuan tertentu. Laba begitu berperan untuk menunjukkan kinerja yang dicapai oleh manajemen, karena investor sangat memperhatikan laba yang dihasilkan perusahaan. Respon investor terhadap laba yang diumumkan juga bervariasi. Laba yang dilaporkan manajemen mempunyai peranan dalam hubungan return laba. Karena bervariasinya respon yang diberikan investor maka perusahaan tentu saja berharap agar investor mempunyai reaksi positif terhadap laba.

Menurut Suwardjono (2005:456), reaksi pasar ditunjukkan dengan adanya perubahan harga dari sekuritas yang bersangkutan. Dimana reaksi ini dapat diukur dengan menggunakan return sebagai nilai perubahan harga atau abnormal return. Salah satu tujuan dilakukannya perataan laba adalah mengurangi laba yang terlalu ekstrim dengan menaikkan atau menurunkan laba dengan menggunakan komponen discretionary accrual. Investor umumnya lebih cenderung menyukai laba yang tidak terlalu berfluktuasi karena mengurangi risiko.

\section{PEMBAHASAN}

\section{Analisa}

\section{a. Income Smoothing pada Perusahaan Sektor Industri Barang Konsumsi yang Terdaftar di Bursa Efek} Indonesia Periode 2010-2013

Income Smoothing adalah upaya yang sengaja dilakukan untuk menormalkan laba dalam rangka mencapai kecenderungan atau tingkat laba yang diinginkan. Faktor yang mempengaruhi Income Smoothing sangat beragam antara lain ukuran perusahaan, profitabilitas, sektor industri, harga saham, leverage, dan rencana bonus. Hal inilah yang merupakan kebutuhan manajemen untuk menetralisir ketidakpastian lingkungan dan menurunkan fluktuasi yang luas dalam kinerja operasi perusahaan terhadap siklus waktu baik maupun buruk secara bergantian.

Dari hasil penelitian, nilai Indeks Eckel maksimum Perusahaan Industri Sektor Barang Konsumsi yaitu mencapai angka 2,435, artinya perusahaan tersebut melakukan perataan laba dalam jumlah yang besar. Hal ini dapat dilihat dari besarnya angka koefisien laba yang tidak sebanding dengan besarnya koefisien penjualan. Di sisi lain ada juga Perusahaan Sektor Industri Barang Konsumsi yang Indeks Eckelnya baik yaitu dibawah angka 1 , yang berarti perusahaan tersebut tidak melakukan tindakan perataan laba.

Untuk nilai Indeks Eckel minimum yaitu mencapai angka -6,058 atau dalam arti perusahaan ini tidak melakukan praktik perataan laba. Nilai minus pada Indeks Eckel mempunyai arti kalau Perusahaan Sektor Indusri Barang Konsumsi tersebut pernah mengalami penurunan laba selama tahun penelitian yang cukup besar sehingga berpengaruh pada koefisien laba. Dari hasil penelitian, angka -6,058 terdapat pada PT. Martina Berto Tbk. Nilai Indeks Eckel perusahaan tersebut berada dibawah nilai 1.

Pada umumnya semakin besar angka Indeks Eckel perusahaan, berarti perusahaan melakukan tindakan perataan laba yang cukup besar. Contoh: pada angka Indeks Eckel $=1$, berarti jumlah koefisien laba masih sebanding dengan jumlah koefisien penjualan. Tetapi pada angka Indeks Eckel diatas 1, berarti jumlah koefisien laba lebih dari jumlah koefisien penjualan. Disini jelas bahwa pada angka Indeks Eckel yang lebih besar disebabkan karena perusahaan melakukan praktik perataan laba pada jumlah yang lebih besar. Dengan demikian bukan berarti jika angka Indeks Eckel lebih besar akan merugikan perusahaan. Namun selama praktik perataan laba masih sesuai dengan Standard Akuntansi Keuangan Indonesia maka hal tersebut masih bisa dianggap wajar dan diperbolehkan.

Dari hasil penelitian, rata-rata nilai Indeks Eckel Perusahaan Sektor Industri Barang Konsumsi selama tahun penelitian adalah rendah yaitu sebesar 0,1589. Angka 0,1589 tersebut mengandung arti bahwa jumlah 
daripada koefisien laba lebih kecil daripada jumlah koefisien penjualan. Angka tersebut juga lebih kecil dari angka 1 yang berarti bahwa perusahaan tidak melakukan praktik perataan laba. Sebaliknya apabila nilai Indeks Eckel semakin besar dari angka 1 maka praktik perataan laba yang dilakukan semakin besar.

Berdasarkan hasil penelitian, ada lima (5) perusahaan dengan nilai Indeks Eckel yang di atas rata-rata. Namun berada di atas rata-rata bukanlah selalu merupakan hal yang tidak baik. Ini dikarenakan adanya perusahaan yang Indeks Eckelnya berada diatas rata-rata namun lebih kecil dari 1. Perusahaan tersebut berhasil menjaga rasio perbandingan antara koefisien laba dengan koefisien penjualan dengan stabil tanpa adanya tindakan perataan laba yang dilakukan.

\section{b. Earning Response pada Perusahaan Sektor Industri Barang Konsumsi yang Terdaftar di Bursa Efek Indonesia Periode 2010-2013}

Informasi laba rugi dikatakan bernilai jika publikasi atas informasi tersebut menyebabkan bergeraknya reaksi pasar. Reaksi pasar ditunjukkan dengan adanya perubahan dari harga sekuritas bersangkutan yang lajimnya diukur dengan menggunakan return saham sebagai nilai perubahannya. Salah satu cara dalam mengukur variabel reaksi pasar adalah dengan menggunakan menggunakan Cummulative Abnormal Return $(C A R)$ yang dihitung pada saat periode peristiwa (event period), yang disebut juga dengan periode pengamatan atau jendela peristiwa. Cummulative Abnormal Return merupakan penjumlahan dari abnormal return pada periode pengamatan.

Dari hasil penelitian, nilai CAR maksimum Objek Penelitian Perusahaan Sektor Industri Barang Konsumsi periode 2010-2013 mencapai angka 0,1332. Angka ini terdapat pada PT. Tiga Pilar Sejahtera Food Tbk pada tahun 2011. Tingginya nilai Cummulative Abnormal Return pada perusahaan ini dikarenakan naiknya harga saham secara terus menerus pada empat hari penelitian. Harga saham perusahaan ini meningkat dari 510 menjadi 580 .

Dari hasil penelitian selanjutnya, diperoleh nilai minimum CAR yaitu sebesar -0,055. Angka ini terdapat pada PT. Tempo Scan Pasific Tbk pada tahun 2013. Kebalikan dari penelitian sebelumnya, rendahnya nilai Cummulative Abnormal Return pada perusahaan ini dikarenakan turunnya harga saham secara terus menerus selama empat hari penelitian. Harga saham perusahaan ini menurun dari 3.350 menjadi 3.050. Dari hasil penelitian, nilai rata-rata Cummulative Abnormal Return pada Objek Penelitian Perusahaan Sektor Industri Barang Konsumsi periode 2010-2013 adalah sebesar 0,0128. Besarnya Cummulative Abnormal Return menunjukkan semakin tingginya harga saham pada perusahaan tersebut.

Berdasarkan hasil penelitian, ada satu (1) perusahaan yang nilai Cummulative Abnormal Returnnya diatas rata-rata, yang berarti bahwa harga saham perusahaan tersebut tinggi. Berdasarkan hasil penelitian selanjutnya, diperoleh lima (5) perusahaan yang nilai Cummulative Abnormal Returnnya di bawah rata-rata, yang berarti harga saham perusahaan tersebut rendah.

\section{c. Income Smoothing dan Earning Response Perusahaan Sektor Industri Barang Konsumsi yang Terdaftar di Bursa Efek Indonesia}

Menurut Suwardjono (2005:456) reaksi pasar ditunjukkan dengan adanya perubahan harga dari sekuritas yang bersangkutan. Dimana reaksi ini dapat diukur dengan menggunakan return sebagai nilai perubahan harga atau abnormal return. Salah satu tujuan dilakukannya perataan laba adalah mengurangi laba yang terlalu ekstrim dengan menaikkan atau menurunkan laba dengan menggunakan komponen discretionary accrual. Investor umumnya lebih cenderung menyukai laba yang tidak terlalu berfluktuasi karena mengurangi risiko.

Dari hasil penelitian, terdapat 3 perusahaan yang melakukan tindakan Income Smoothing yaitu PT. Kimia Farma (Persero) Tbk dengan Indeks Eckel sebesar 1,65125783, PT. Kalbe Farma Tbk dengan Indeks Eckel sebesar 2,43573709, dan PT. Tempo Scan Pasific Tbk dengan Indeks Eckel sebesar 1,81257083. Tiga perusahaan tersebut juga memiliki rata-rata Cummulative Abnormal Return yang tinggi yaitu PT. Kimia Farma (Persero) Tbk sebesar 1,825628914, PT. Kalbe Farma Tbk sebesar 2,17868545, dan PT. Tempo Scan Pasific Tbk sebesar 3,906285417.

Dari hasil penelitian selanjutnya, terdapat 2 perusahaan yang tidak melakukan tindakan Income Smoothing yaitu: PT. Tiga Pilar Sejahtera Food Tbk dengan Indeks Eckel sebesar 0,60089620 dan PT. Martina Berto Tbk dengan Indeks Eckel sebesar -6,05856547. Dua perusahaan tersebut juga memiliki rata-rata Cummulative Abnormal Return yang rendah yaitu PT. Tiga Pilar Sejahtera Food Tbk sebesar 0,800448099 dan PT. Martina Berto Tbk sebesar -1,029282735. Pada penelitian ini juga ditemukan bahwa ada satu perusahaan yang tidak melakukan tindakan Income Smoothing namun memiliki Earning Response yang besar. Ini terdapat pada PT. Mandom Indonesia Tbk yang memiliki nilai Indeks Eckel sebesar 0,51155220, namun nilai Cummulative Abnormal Return sebesar 2,755776102.

\section{Evaluasi}

a. Income Smoothing Pada Objek Penelitian Perusahaan Sektor Barang Konsumsi yang Terdaftar di Bursa Efek Indonesia 
Dari hasil penelitian, rata-rata nilai Indeks Eckel Perusahaan Sektor Industri Barang Konsumsi selama tahun 2010-2013 adalah rendah yaitu sebesar 0,1589. Angka 0,1589 tersebut mengandung arti bahwa jumlah daripada koefisien laba lebih kecil daripada jumlah koefisien penjualan. Angka tersebut juga lebih kecil dari angka 1 yang berarti bahwa perusahaan tidak melakukan praktik perataan laba. Sebaliknya apabila nilai Indeks Eckel semakin besar dari angka 1 maka praktik perataan laba yang dilakukan semakin besar.

Nilai Indeks Eckel > 1 pada Perusahaan Sektor Industri Barang Konsumsi menunjukkan bahwa perusahaan melakukan praktik perataan laba. Semakin besar nilai Indeks Eckel dari 1 maka semakin besar perusahaan melakukan perataan laba. Nilai Indeks Eckel > 1 terdapat pada PT. Kimia Farma (Persero) Tbk, PT. Kalbe Farma Tbk, dan PT. Tempo Scan Pasific Tbk. Sedangkan untuk Indeks Eckel $\leq 1$ menunjukkan bahwa perusahaan melaporkan laba dan penjualan perusahaan dengan benar adanya tanpa adanya tindakan perataan laba. Nilai Indeks Eckel $\leq 1$ terdapat pada PT. Tiga Pilar Sejahtera Food Tbk, PT.Martina Berto Tbk, dan PT. Mandom Indonesia Tbk.

Penelitian ini tidak membahas apakah tingkat rata-rata Indeks Eckel sebesar 0,1589 yang dihasilkan oleh Perusahaan Sektor Industri Barang Konsumsi yang terdaftar di Bursa Efek Indonesia sudah cukup baik dibanding dengan tingkat rata-rata Indeks Eckel di sektor lain yang terdaftar di Bursa Efek Indonesia.

\section{b. Earning Response Pada Objek Penelitian Perusahaan Sektor Industri Barang Konsumsi yang Terdaftar di Bursa Efek Indonesia}

Dari hasil penelitian, nilai rata-rata Cummulative Abnormal Return pada Objek Penelitian Perusahaan Sektor Industri Barang Konsumsi periode 2010-2013 adalah sebesar 0,0128. Besarnya Cummulative Abnormal Return menunjukkan semakin tingginya harga saham pada perusahaan tersebut. Namun demikian, diantara objek penelitian yang diteliti, ada Perusahaan Sektor Industri Barang Konsumsi yang nilai Cummulative Abnormal Returnnya mencapai 0,1332 yaitu PT. Tiga Pilar Sejahtera Food Tbk pada tahun 2011. Hal ini berarti harga saham perusahaan ini mengalami peningkatan besar.

Semakin rendahnya nilai CAR suatu perusahaan mengindikasikan harga saham perusahaan yang semakin menurun. CAR juga memberikan sinyal kepada perusahaan atas reaksi pasar. Penelitian ini tidak membahas apakah tingkat rata-rata Cummulative Abnormal Return (CAR) sebesar 0,0128 yang dihasilkan oleh Objek Penelitian Perusahaan Sektor Industri Barang Konsumsi yang terdaftar di Bursa Efek Indonesia sudah cukup baik dibanding dengan tingkat rata-rata Cummulative Abnormal Return (CAR) di sektor lain yang Terdaftar di Bursa Efek Indonesia.

\section{c. Income Smoothing dan Earning Response Pada Objek Penelitian Perusahaan Sektor Industri Barang Konsumsi yang Terdaftar di Bursa Efek Indonesia}

Berdasarkan hasil penelitian, nilai Indeks Eckel yang tinggi pada Objek Penelitian Perusahaan Sektor Industri Barang Konsumsi periode 2010-2013 selalu diikuti dengan rata-rata Cummulative Abnormal Return yang tinggi. Sementara nilai Indeks Eckel yang rendah pada Objek Penelitian Perusahaan Sektor Industri Barang Konsumsi periode 2010-2013 akan diikuti dengan rata-rata Cummulative Abnormal Return yang rendah. Kedua hal ini sesuai dengan teori yang dikemukakan oleh Suwardjono (2005:456), bahwa Income Smoothing mempengaruhi Earning Response. Sementara itu, ditemukan fakta bahwa pada PT. Mandom Indonesia Tbk tidak melakukan tindakan Income Smoothing namun memiliki Earning Response yang tinggi. Hal ini dapat dijelaskan dengan teori yang dikemukakan oleh Alwi (2003:87), bahwa Earning Response dapat dipengaruhi oleh faktor internal seperti pengumuman tentang pemasaran, produksi, penjualan dan juga faktor external seperti pengumuman dari pemerintah.

Berdasarkan data dan uraian di atas, maka Perusahaan Sektor Industri Barang Konsumsi yang Terdaftar di Bursa Efek Indonesia Periode 2010-2013 yang telah melakukan praktik Income Smoothing diikuti dengan meningkatnya Earning Response. Dengan demikian hipotesis dapat diterima.

\section{KESIMPULAN DAN SARAN}

\section{Kesimpulan}

a. Dari hasil penelitian, ditemukan bahwa jumlah perusahaan yang melakukan praktik Income Smoothing sebanding dengan perusahaan yang tidak melakukan praktik Income Smoothing. Hal ini ditunjukkan dengan adanya 3 perusahaan yang melakukan praktik Income Smoothing dari total 6 objek penelitian Perusahaan Sektor Industri Barang Konsumsi yang Terdaftar di Bursa Efek Indonesia.

Dari hasil penelitian, didapat bahwa nilai Indeks Eckel minimum mencapai angka -6,0585.ini menunjukkan bahwa masih terdapat perusahaan yang tidak melakukan tindakan Income Smoothing walaupun perusahaan tersebut mengalami penurunan laba. Sementara nilai Indeks Eckel maksimum mencapai angka 2,435. Ini membuktikan bahwa perusahaan dapat melakukan tindakan Income Smoothing dalam jumlah yang signifikan selama masih sesuai dengan Standar Akuntansi Keuangan Indonesia.

b. Dari hasil penelitian, nilai rata-rata Cummulative Abnormal Return pada Objek Penelitian Perusahaan Sektor Industri Barang Konsumsi periode 2010-2013 adalah sebesar 0,0128. Besarnya Cummulative Abnormal 
Return menunjukkan Earning Response terhadap harga saham pada perusahaan tersebut. Sementara nilai minimum Cummulative Abnormal Return pada Objek Penelitian Perusahaan Sektor Industri Barang Konsumsi periode 2010-2013 adalah sebesar -0,055. Nilai Cummulative Abnormal Return yang bernilai minus menunjukkan bahwa Earning Response yang berkurang disebabkan karena harga saham perusahaan yang menurun dalam jumlah yang cukup besar.

c. Berdasarkan penelitian atas Hubungan Income Smoothing dan Earning Response Objek Penelitian Perusahaan Sektor Industri Barang Konsumsi yang Terdaftar di Bursa Efek Indonesia Periode 2010-2013 menunjukkan bahwa tindakan Income Smoothing diikuti dengan meningkatnya Earning Response.

\section{Saran}

a. Bagi investor dan calon investor disarankan untuk terlebih dahulu menganalisis tingkat Income Smoothing khususnya dengan memperhatikan Indeks Eckel perusahaan sebelum berinvestasi karena Income Smoothing sering kali dilakukan oleh perusahaan.

b. Bagi perusahaan disarankan melaporkan laba yang sebenarnya tanpa melakukan Income Smoothing. Karena fakta menunjukkan kalau ada perusahaan yang tetap sanggup bertahan walaupun tidak melakukan tindakan Income Smoothing.

c. Perusahaan juga diharapkan dapat menjaga harga saham untuk mendapatkan Earning Response yang bagus.

d. Bagi peneliti selanjutnya

Mengingat keterbatasan penulis, skripsi yang ditulis penulis masih jauh dari sempurna karena masih banyak kelemahan dan kekurangan di dalamnya. Untuk itu, bagi peneliti selanjutnya diharapkan:

a. Menggunakan objek penelitian yang tidak hanya terbatas pada Perusahaan Sektor Industri Barang Konsumsi saja, tetapi pada seluruh perusahaan yang tercatat di Bursa Efek Indonesia untuk mendapatkan kesimpulan yang lebih tepat.

b. Melakukan penelitian dengan menggunakan rasio Income Smoothing selain daripada Indeks Eckel.

\section{E. DAFTAR PUSTAKA}

Alwi, Iskandar, 2003, Pasar Modal, Teori dan Aplikasi, Jakarta: Yayasan Pancur Siwah.

Baridwan, Zaki, 2004, Intermediate Accountiing, Edisi Kedelapan, Yogyakarta: BPFE.

Belkaoui, Ahmed, 2007, Accounting Theory, Buku dua, Jakarta: Salemba Empat.

Dedhy, Sulistiawan et.al, 2011, Creative Accounting (Mengungkap Manajemen Laba dan Skandal Akuntansi), Jakarta: Salemba Empat.

Husnan. S, 2005, Teori Portofolio dan Analisis Sekuritas, Edisi Kelima, Yogyakarta: BPFE.

Jogiyanto, 2000, Teori Portofolio dan Analisis Investasi, BPFE: Yogyakarta.

Scott, William. R, 2000, Financial Accounting Theory, Edisi kedua, Canada:Prentice Hall.

Simamora, Bilson, 2002, Panduan Riset Perilaku Konsumen, Surabaya: Pustaka Utama.

Suwardjono, 2005, Teori Akuntansi: Perekayasaan Pelaporan Keuangan, Edisi 3, Yogyakarta: BPFE. 